\title{
THE TOTAL ANTIOXIDANT CAPACITY MAY NOT BE RELATED TO BILIRUBIN AND URIC ACID LEVEL IN PATIENTS WITH BETA THALASSEMIA
}

\author{
BETA TALASEMI HASTALARINDA TOTAL ANTIOKSIDAN KAPASITESI BILIRUBIN VE \\ ÜRIK ASIT SEVIYESI ILE ILIŞKILI DEĞILDIR
}

\author{
Zeynep KARAKAŞ ${ }^{1}$ (D), Yasin YILMAZ1,2 (D), Dolay Damla ÇELIK ${ }^{3}$ (D), Agageldi ANNAYEV4 (D), Serap ERDEM KURUCA³ (D) \\ ${ }^{1}$ Istanbul University, Istanbul Faculty of Medicine, Department of Pediatrics, Division Pediatrics Hematology, Thalassemia Center, Turkey \\ ${ }^{2}$ istanbul University, Institute of Health Sciences, Aziz Sancar Institute of Experimental Medicine, Department of Neuroscience, Istanbul, Turkey \\ ${ }^{3}$ Istanbul University, Istanbul Faculty of Medicine, Department of Physiology, Turkey \\ ${ }^{4}$ Acıbadem Hospital, Department of Pediatrics, Istanbul, Turkey
}

ORCID IDs of the authors: Z.K. 0000-0002-8835-3235; Y.Y. 0000-0002-4811-5750; D.D.Ç. 0000-0002-7523-8465; A.A. 0000-0002-9780-4843; S.E.K. 0000-0002-5566-7844

Cite this article as: Karakas Z, Yilmaz Y, Celik DD, Annayev A, Erdem Kuruca S. The total antioxidant capacity may not be related to bilirubin and uric acid level in patients with beta thalassemia. J Ist Faculty Med 2020;83(4):373-7. doi: 10.26650/IUITFD.2020.0013

\begin{abstract}
Objective: Iron burden resulting from ineffective erythropoiesis and multiple transfusions can cause oxidative stress in patients with $B$-thalassemia. Here we aimed to examine the total antioxidant and oxidant capacity (TAC and TOC) along with its relation to endogenous antioxidants (bilirubin and uric acid) in patients with B-thalassemia.
\end{abstract}

Material and Method: Forty-five patients with transfusion-dependent (TDT) $(n=30)$ and non-transfusion-dependent (NTDT) $(n=15)$ B-thalassemia and 20 healthy subjects were enrolled in the study. Analyses were done using Total Antioxidant Status (TAS) and Total Oxidant Status (TOS) kits.

Results: The TAC level of the patients was significantly increased compared to healthy subjects ( 2.75 vs. $2.10 \mathrm{mmol} / \mathrm{L} ; \mathrm{p}=0.01)$. The total bilirubin level was significantly elevated in NTDT patients compared to TDT patients $(5.7 \pm 3.3$ vs. $1.9 \pm 1.4 ; \mathrm{p}<0.001)$. No significant relationship between endogenous antioxidants and total antioxidant capacity of patients was detected $(p=0.20)$ Conclusion: The total antioxidant capacity of patients with B-thalassemia might not be directly related to endogenous anti-oxidative status.

Keywords: Beta-thalassemia, antioxidant capacity, oxidant capacity, endogenous antioxidant

\section{ÖZET}

Amaç: Beta talasemi hastalarında inefektif eritropoez ve çoklu transfüzyonlardan kaynaklanan demir birikimi, hastaları oksidatif strese maruz bırakmaktadır. Bu çalışmada, beta talasemi hastalarında total antioksidan ve oksidan kapasiteleri ile bunların endojen antioksidanlar (bilirubin, ürik asid) arasındaki ilişkinin değerlendirilmesi amaçlanmıştır.

Gereç ve Yöntemler: Çalışmaya transfüzyon bağımlı 30, transfüzyon bağımlı olmayan 15 olmak üzere kırk beş beta talasemi hastası ve 20 sağlıklı birey katılmıştır. Analiz için total antioksidan ve total oksidan durum kitleri kullanılmıştır.

Bulgular: Hastaların total antioksidan kapasitesi (TAK) sağlıklı bireylere göre anlamlı olarak yüksek saptanmıştır (2,75 vs. 2,10 $\mathrm{mmol} / \mathrm{L} ; \mathrm{p}=0,01)$. Total bilirubin seviyesi transfüzyon bağımlı olmayan hastalarda, transfüzyon bağımlı hastalara oranla anlamlı

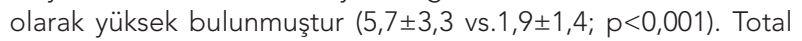
antioksidan kapasite ile endojen antioksidan seviyeleri arasında anlamlı ilişki saptanmamıştır $(p=0,20)$

Sonuç: Beta talasemi hastalarının total antioksidan kapasitesi, hastaların endojen antioksidan durumları ile direkt ilişkili olmayabilir.

Anahtar Kelimeler: Beta talasemi, antioksidan kapasitesi, oksidan kapasitesi, endojen antioksidan

Corresponding author/iletişim kurulacak yazar: zeynepkar@hotmail.com

Submitted/Başvuru: 24.09.2019 • Revision Requested/Revizyon Talebi: 13.02.2020 •

Last Revision Received/Son Revizyon: 14.02.2020 • Accepted/Kabul: 02.03.2020 • Published Online/Online Yayın: 21.09.2020

(C)Telif Hakkı $2020 \mathrm{~J}$ Ist Faculty Med - Makale metnine jmed.istanbul.edu.tr web sayfasından ulaşılabilir.

(C) Copyright 2020 by J Ist Faculty Med - Available online at jmed.istanbul.edu.tr 


\section{INTRODUCTION}

B-thalassemia (BT) is a common monogenic disease. The Thalassemia International Federation (TIF) classifies thalassemia syndromes as either transfusion-dependent (TDT) or non-transfusion-dependent thalassemia (NTDT) (1).

Transfusion-dependent thalassemia patients need lifelong periodic blood transfusions. However, the complications of transfusions (mainly iron deposition) cause oxidative reactions, and iron chelation treatment is used to avoid iron-originated oxidative damage (2). To overcome oxidative stress, the body also uses endogenous (uric acid, bilirubin, and enzymes) antioxidant mechanisms.

Recently, total antioxidant capacity assays have become readily available and widely used (3). To use simple kits is much more convenient than attempting to measure the separate antioxidant statuses of the body. Our aim in this study was to evaluate the antioxidant and oxidant capacity of thalassemic patients and to reveal its association with endogenous antioxidants (uric acid, bilirubin).

\section{MATERIAL AND METHOD}

\section{Participants}

Twenty female and 25 male patients with $\beta$-thalassemia [mean $( \pm S D)$ age $=27.3 \pm 9$ years; range, 12-59 years] (non-transfusion-dependent $n=15$, transfusion-dependent $n=30$ ) from Istanbul Medical Faculty Thalassemia Center, along with a healthy control group comprised of 15 women and five men [mean $( \pm S D)$ age $=31.9 \pm 8$ years; range, 18-45 years)], were recruited into the study. Eighty-four percent of patients were treated with deferasirox (DFX), and $11 \%$ of them were taking deferiprone (DFP). Two patients used no chelators. Fifty-three percent of the patients had undergone splenectomy. The mean ferritin level was $1410 \pm 1087 \mathrm{ng} / \mathrm{mL}$, and almost half of the patients (48\%) had a ferritin level of less than $1000 \mathrm{ng} / \mathrm{ml}$.

The patients were recruited from a group of regularly followed-up outpatient patients who regularly came into the clinic for check-ups. During the study period, which was open for 3 months, patients with B-thalassemia were asked to participate in the study. Researcher was in the clinic one day a week and met with the informed patients. Patients with acute infections (e.g., respiratory, gastrointestinal) and recent surgery history were not included in the study. Each patient's serum analysis (TAC and TOC level) was checked at the end of the study period. The healthy control group was recruited from among hospital staff (without any infection or chronic disorder). As the study period was restricted, only a limited number of healthy people participated in the trial.

\section{Oxidant and antioxidant kits}

TAC was used clinically as a biomarker measuring the antioxidant status of the body and was seen as more practical than measuring antioxidants individually owing to their synergistic interaction $(4,5)$. The total antioxidant and oxidant capacity were analyzed using Rel Assay Diagnostics kits (Turkey). The kits had Trolox Equivalent Antioxidant Capacity (TEAC) to analyze samples (6). Blood samples (serum) were gathered from patients and analyzed in a laboratory. To prevent the transfusion-related acute changes, blood sampling was carried out just before transfusion.

\section{Statistics}

The SPSS 21.0 (IBM Corp) software package was used for statistical analysis. For the evaluation of categorical variables, the Chi-square test was used. For the comparison of the two groups, the Mann-Whitney $U$ test and Student's t-test were used. For the relationship between continuous variables, Pearson's and Spearman's tests were performed. P-values of $<0.05$ were considered significant.

\section{RESULTS}

Patients with transfusion-dependent and non-dependent thalassemia did not differ in terms of total antioxidant capacity (TAC) $(2.76 \pm 0.65$ and $2.72 \pm 1.25 \mathrm{mmol} / \mathrm{L}, \mathrm{p}=0.90$, respectively). The TOC levels of patients with TDT and NTDT were $18.76 \pm 15.05$ and $31.96 \pm 33.02 \mu \mathrm{mol} / \mathrm{L}$, respectively $(p=0.15)$ (Figure 1).

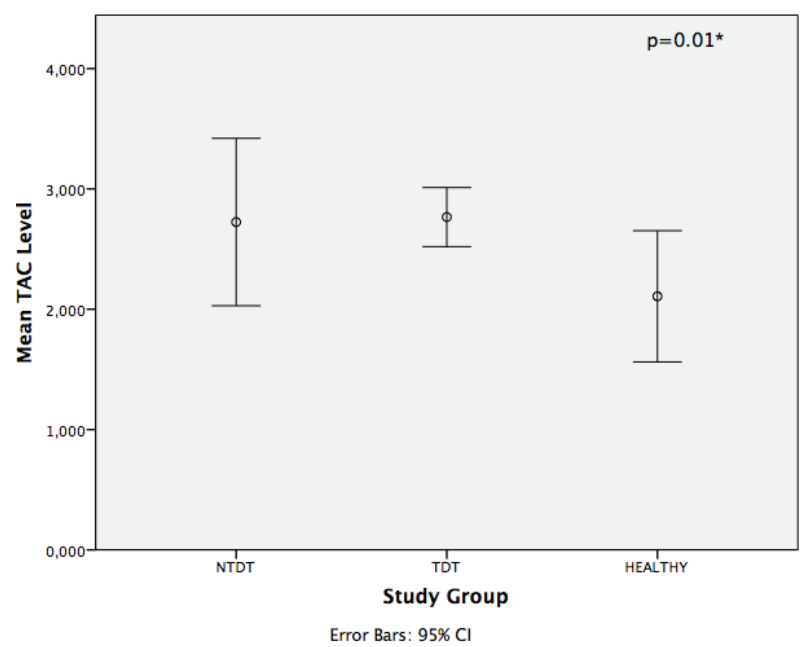

Figure 1: The mean TAC level in study group. ${ }^{*} p$ value lower than 0.05 is significant

The TAC level of the patients was significantly higher than in the healthy group $(2.75 \pm 0.88$ vs. $2.10 \pm 1.16$ $\mathrm{mmol} / \mathrm{L}, \mathrm{p}=0.01$ ). However, the TOC level did not significantly differ between the patients and the healthy group (23.16 \pm 23.15 vs. $16.79 \pm 11.87 \mu \mathrm{mol} / \mathrm{L}, \mathrm{p}=0.25)$ (Figure 1). The total bilirubin level was significantly higher in the 
Table 1. Laboratory values of study groups.

\begin{tabular}{lccc}
\hline Characteristics & NTDT group & TDT group & Statistics \\
Ferritin & $796 \pm 718 \mathrm{ng} / \mathrm{ml}$ & $1728 \pm 1119 \mathrm{ng} / \mathrm{ml}$ & $\mathrm{p}=0.002^{*}$ \\
Bilirubin & $5.7 \pm 3.3 \mathrm{mg} / \mathrm{dl}$ & $1.9 \pm 1.4 \mathrm{md} / \mathrm{dl}$ & $\mathrm{p}<0.001^{*}$ \\
Uric Acid & $3.8 \pm 1.2 \mathrm{mg} / \mathrm{dl}$ & $4.2 \pm 1.2 \mathrm{md} / \mathrm{dl}$ & $\mathrm{p}=0.52$ \\
Albumin & $4.9 \pm 0.4 \mathrm{~g} / \mathrm{dl}$ & $4.8 \pm 0.2 \mathrm{~g} / \mathrm{dl}$ & $\mathrm{p}=0.51$ \\
ALT & $22.6 \pm 19.6 \mathrm{U} / \mathrm{l}$ & $30.2 \pm 25.0 \mathrm{U} / \mathrm{l}$ & $\mathrm{p}=0.32$ \\
AST & $24.1 \pm 8.8 \mathrm{U} / \mathrm{l}$ & $27.7 \pm 11.6 \mathrm{U} / \mathrm{l}$ & $\mathrm{p}=0.30$ \\
\hline
\end{tabular}

${ }^{*} p$ value lower than 0.05 is significant

NTDT group than the TDT group $(5.7 \pm 3.3$ vs. $1.9 \pm 1.4 \mathrm{mg} /$ $d l, p<0.001)$. The uric acid level did not differ between the NTDT and TDT groups (3.8 \pm 1.2 vs. $4.2 \pm 1.2 \mathrm{mg} / \mathrm{dl}$; $p=0.52$ )(Table 1). We detected no significant correlations between TAC and TOC levels and endogenous antioxidants (uric acid and bilirubin).

A simple linear regression was used to predict the TAC level based on the serum uric acid level. No significance was found $(F(1,24)=1.71, p=0.20)$ with an $R^{2}$ of 0.06 . Likewise, linear regression was also done to predict TOC level based on uric acid, and no significance was found $(F(1,24)=0.01, p=0.91)$ with an $R^{2}$ of -0.04 . Similar regression results were obtained for the correlation between total bilirubin level with TAC and TOC level $(p=0.94$ and $p=0.27$, respectively).

The mean WBC of patients was $13,030 \pm 13,100 / \mathrm{mm}^{3}$, and the mean hemoglobin level was $9.2 \pm 1.5 \mathrm{gr} / \mathrm{dl}$. There was no correlation between the TAC level with WBC and hemoglobin level ( $p=0.28$ and $p=0.27$, respectively).

Both the TAC and TOC levels were higher (non-significantly) in the DFX group than in the DFP group of all

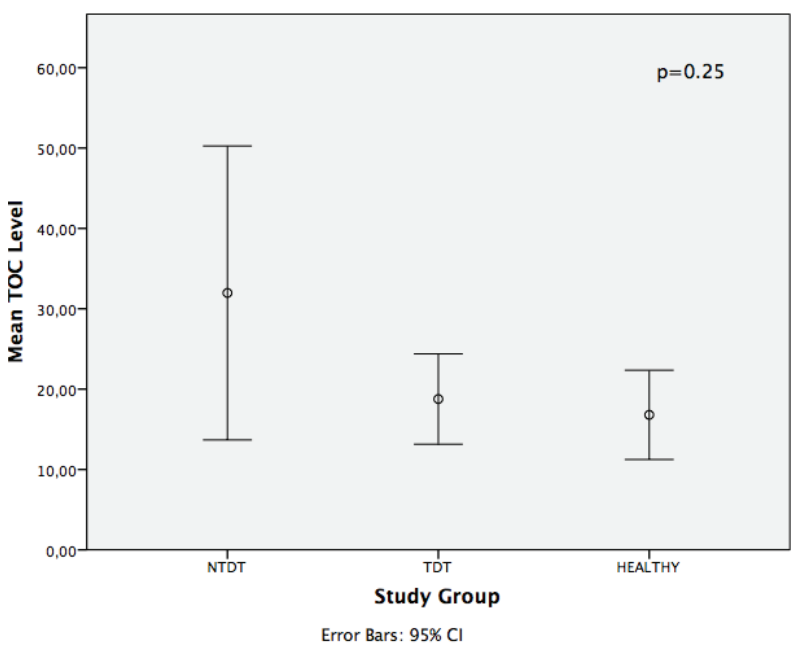

Figure 2: The mean TOC level in study group.
B-thalassemia patients ( 2.77 vs. $2.48 \mathrm{mmol} / \mathrm{L}$ for TAC and 24.36 vs. $17.94 \mu \mathrm{mol} / \mathrm{L}$ for TOC). We detected no significant associations between TAC and TOC levels with age, gender, splenectomy, or ferritin level.

\section{DISCUSSION}

In this study, we found that TAC levels were significantly increased in B-thalassemia patients compared to the control group. Among thalassemic patients, the TDT group had higher TAC levels, and the NTDT group had higher TOC levels, but these differences did not reach statistical significance. The endogen antioxidant and total bilirubin levels were significantly elevated in the NTDT group.

Iron overload continues to be the main problem in patients with thalassemia. Frequent transfusions, ineffective erythropoiesis, and inadequate iron excretory pathways cause iron deposition (7). Accumulation of iron can cause reactive oxygen species (ROS), which, in turn, leads to oxidative stress (8).

Several studies have investigated the oxidant-antioxidant status of patients with thalassemia (9-13). Asif et al. (9) detected high levels of TOC and TAC in children with thalassemia. In our study, we also found high levels of TAC in the patient group. However, we detected no increase in TOC levels in the patient group. This controversial data led us to speculate that antioxidant status might not be dependent on the body oxidant status of endogenous body antioxidant (bilirubin and uric acid) status.

Ferro et al. (10) argued that the higher hemoglobin levels provided by regular transfusions help limit oxidative damage. However, we detected no difference in the hemoglobin levels in the thalassemic group and no correlations between hemoglobin level and TAC and TOC levels.

Another study (11) reported high levels of TAC in patients with thalassemia. According to this author's proposals, 
more transfusions necessitate higher antioxidant status. In our study, TDT showed a higher, but insignificant, antioxidant capacity. We also found that bilirubin (endogenous antioxidant molecule) was elevated in the NTDT patients.

Several studies found controversially low levels of TAC in patients with thalassemia. Cakmak et al. reported non-significant differences in TAC levels (12). Hamed et al. found decreased TAC levels in patients receiving chelation therapy (13). They also showed that TAC levels were significantly lower than those without chelation therapy. We detected no differences between the two chelators in terms of TAC levels, possibly because of a disproportionate number of patients using chelation (38 vs. 5). On the other hand, there were only two patients who did not use chelation. Therefore, it is difficult to speculate about the chelation effect on antioxidant capacity.

Interestingly, a recent meta-analysis showed that TAC levels were decreased in patients with thalassemia (14). Taken together, the findings of these studies suggest that the antioxidant capacity of patients with thalassemia is more complicated than we currently think. A limitation of this study was the small sample size. Insufficient data on the patients' dietary intake is a further limitation.

\section{CONCLUSION}

Here we report an increase in the anti-oxidative status in patients with thalassemia. Many factors influence anti-oxidative mechanisms, such as high levels of endogenous antioxidants and chelation therapy. These controversial results show that more studies are necessary to delineate the antioxidant mechanism of beta-thalassemia patients.

Acknowledgments: We thank Mr. David Chapman for copyediting the manuscript in English language.

Ethics Committee Approval: This study was approved by Istanbul University Istanbul Faculty of Medicine Clinical Research Ethics Committee (05/2014).

Informed Consent: Written consent was obtained from the participants.

Peer Review: Externally peer-reviewed.

Author Contributions: Conception/Design of Study- Z.K., A.A., S.E.K.; Data Acquisition- D.D.Ç., A.A.; Data Analysis/Interpretation- Z.K., Y.Y., D.D.Ç.; Drafting Manuscript- Y.Y., A.A., D.D.Ç.; Critical Revision of Manuscript- Z.K., S.E.K.; Final Approval and Accountability- Z.K., Y.Y., D.D.Ç., A.A., S.E.K.; Technical or Material Support- Z.K., D.D.Ç.; Supervision- Z.K.
Conflict of Interest: Authors declared no conflict of interest.

Financial Disclosure: This study was supported by Istanbul University Scientific Research Projects.

Teşekkür: Yazıyı ingilizce dili açııından düzenlediği için David Chapman'a teşekkür ederiz.

Etik Komite Onayı: Bu çalışma için etik kurul onayı İstanbul Üniversitesi İstanbul Tıp Fakültesi Klinik Araştırmalar Etik Kurulu'ndan alınmıştır (05/2014).

Bilgilendirilmiş Onam: Katılımcılardan bilgilendirilmiş onam alınmıştır.

Hakem Değerlendirmesi: Dış bağımsız.

Yazar Katkıları: Çalışma Konsepti/Tasarım- Z.K., A.A., S.E.K.; Veri Toplama- D.D.Ç., A.A.; Veri Analizi/Yorumlama- Z.K., Y.Y., D.D.Ç.; Yazı Taslağı- Y.Y., A.A., D.D.Ç.; İçeriğin Eleştirel İncelemesi- Z.K., S.E.K.; Son Onay ve Sorumluluk- Z.K., Y.Y., D.D.Ç., A.A., S.E.K.; Malzeme ve Teknik Destek- Z.K., D.D.Ç.; Süpervizyon- Z.K.

Çıkar Çatışması: Yazarlar çıkar çatışması beyan etmemişlerdir.

Finansal Destek: Bu çalışma İstanbul Üniversitesi Bilimsel Araştırma Projeleri kapsamında desteklenmiştir.

\section{REFERENCES}

1. Viprakasit V, Origa R. Genetic basis, pathophysiology and diagnosis. In: Cappellini MD, Cohen A, Porter J, Taher A, Viprakasit $V$, eds. Guidelines for the management of transfusion dependent thalassaemia (TDT). Nicosia: Thalassaemia International Federation (TIF) Publication, No. 20, third ed; 2014. p. 14-26.

2. Rund D, Rachmilewitz E. Beta-thalassemia. N Engl J Med 2005;353:1135-46. [CrossRef]

3. Bartosz G. Non-enzymatic antioxidant capacity assays: Limitations of use in biomedicine. Free Radic Res 2010;44(7):711-20. [CrossRef]

4. Apak R, Gorinstein S, Böhm V, Schaich KM, Ozyurek M, Guclu K. Methods of measurement and evaluation of natural antioxidant capacity/activity (IUPAC Technical Report). Pure Appl. Chem 2013;85:957-98. [CrossRef]

5. Niki E. Assessment of Antioxidant Capacity in vitro and in vivo. Free RadicBiol Med 2010;49:503-15. [CrossRef]

6. Dilis V, Trichopoulou A. Assessment of antioxidants in foods and biologicalsamples: a short critique. Int J Food Sci Nutr 2010;61(5):441-8. [CrossRef]

7. Rachmilewitz EA, Giardin PJ. How I treat thalassemia. Blood 2011;118:3479-88. [CrossRef]

8. Taher AT, Weatherall DJ, Cappellini MD. Thalassaemia. Lancet 2018;391:155-67. [CrossRef]

9. Asif M, Manzoor Z, Farooq MS, Munawar SH, Aziz A, Khan IA. Status of oxidant, antioxidantand serum enzymes in thalassaemic children receiving multiple blood transfusions. J Pak Med Assoc 2015;65(8):838-43.

10. Ferro E, Visalli G, La Rosa MA, Civa R, Papa GR, D'Ascola $D G$, et al. The role of anaemia in oxidative and genotoxic damage in transfused B-thalassaemic patients. Hematology 2017;22:183-91. [CrossRef] 
11. Bazvand F, Shams S, BorjiEsfahani M, Koochakzadeh L, Monajemzadeh M, Ashtiani MT, et al. Total Antioxidant Status in Patients with Major B-Thalassemia. Iran J Pediatr 2011;21(2):159-65.

12. Cakmak A, Soker M, Koc A, Erel O. Paraoxonase and arylesteraseactivity with oxidative status in children with thalassemia major. J Pediatr Hematol Oncol 2009;31:583-7. [CrossRef]
13. Hamed EA, El Melegy NT. Renal functions in pediatric patients withbeta-thalassemia major: relation to chelation therapy: originalprospective study. Ital J Pediatr 2010;36:3942. [CrossRef]

14. Manafikhi H, Drummen G, Palmery M, Peluso I. Total Antioxidant Capacity in beta-thalassemia: A systematic review and meta-analysis of case-control studies. Crit Rev Oncol Hematol 2017;110:35-42. [CrossRef] 